\title{
LA PROMOCIÓN ARTÍSTICA EN LA CATEDRALES ESPAÑOLAS A TRAVÉS DE LAS RELACIONES ENTRE EL ALTO CLERO SECULAR Y LA MONARQUÍA. LOS OBISPOS DON BALTASAR de Moscoso y Sandoval y don Agustín Rubín de Ceballos
}

\author{
Felipe Serrano Estrella \\ Universidad de Jaén
}

Resumen: Con frecuencia, las fluidas relaciones entre la Corona española y el alto clero secular se plasmaron en una intensa promoción artística. Obispos y cabildos aprovecharon sus contactos en la corte para obtener los medios económicos con los que hacer frente a la construcción de sus catedrales. Asimismo se favoreció el intercambio de artistas y obras de arte entre las diferentes diócesis y Madrid. Los réditos económicos que trajo consigo el desempeño de los altos oficios religiosos y de la administración del Estado fueron invertidos en el fomento de las artes.

Palabras clave: promoción artística, catedrales, Baltasar de Moscoso y Sandoval, Agustín Rubín de Ceballos, Barroco.

Abstract: Good relationships between the Spanish Crown and the senior clergy frequently resulted in a great promotion of the arts. Bishops and canons used their contacts in the Court to obtain financial resources. Thanks to these resources, they could meet the challenge of building cathedrals. It also encouraged the exchange of artists and works of art between the different Spanish dioceses and Madrid. The financial resources from the performance of high religious services and the State administration were invested in the promotion of the arts.

Keywords: Promotion of arts, cathedrals, Baltasar de Moscoso y Sandoval, Agustín Rubín de Ceballos, Baroque. 


\section{INTRODUCCIÓN}

$\mathrm{B}_{\mathrm{s} i}^{\mathrm{ie}}$ en conocida es la estrecha relación que existió entre la Corona y la Iglesia durante el Antiguo Régimen, consecuencia del teocentrismo con el que se configuró el orden político y social de la Edad Moderna. Por otra parte, también ha sido ampliamente estudiado el papel que el arte juega en la estructuración de ese determinado orden. ${ }^{1}$ Ahora bien, no se han analizado de la misma forma los mecanismos y pasos seguidos para tal fin. En este trabajo nos proponemos contribuir a un conocimiento más preciso de los vínculos entre las dos instituciones y el modo en el que fueron cultivados para conformar magníficos programas artísticos. Para ello analizaremos principalmente la acción promotora de las artes desempeñada por los obispos don Baltasar de Moscoso y Sandoval (1589-1665) y don Agustín Rubín de Ceballos (17241793). Pese a tratarse de dos figuras de siglos diferentes, ambos materializaron una realidad que tuvo su parangón en otros muchos prelados españoles. Las conexiones que mantuvieron con la Corona y sus acciones diplomáticas posibilitaron la consecución de importantes empresas artísticas en las diócesis que gobernaron.

La gran fluidez de la que gozaron las relaciones entre la Corona y el alto clero secular se tradujo en una abundante correspondencia entre la monarquía y los obispos, así como con los miembros de los cabildos catedralicios. Las noticias de los principales hechos que acontecían al rey y a los suyos se traducían en todo tipo de celebraciones, que abarcaban desde las más gozosas hasta las más preocupantes y tristes. También la Corona pidió la colaboración de los cabildos para el fomento de devociones, por ejemplo hacia la Inmaculada Concepción y san Fernando.

1. Algunos de los trabajos de referencia: Ricardo García Villoslada, Historia de la Iglesia en España, vols. III-IV, Editorial Católica, Madrid, 1979-1982; Antonio Domínguez Ortiz, Las clases privilegiadas en el Antiguo Régimen, Istmo, Madrid, 1995; Quintín Aldea Vaquero, Política y religión en los albores de la Edad Moderna, Real Academia de la Historia, Madrid, 1999; Antonio Luis Cortés PeÑA, «Monarquía e Iglesia», Historiar: Revista de Historia, 1, 1999, 397-441; TeÓfanes Egido López, «El Real Patronato» en Miguel Luis López-Guadalupe Muñoz, Antonio lara Ramos y Antonio Luis Cortés PeÑa (coords.), Iglesia y sociedad en el reino de Granada (siglos XVI-XVII), Universidad de Granada, Granada, 2003, 9-21; Maximiliano Barrio Gonzalo, El Real Patronato y los obispos españoles del Antiguo Régimen (1556-1834), Centro de Estudios Políticos y Constitucionales, Madrid, 2004; Henar Llorente y José Martínez Millán, «La capilla real: integración social y definición de la ortodoxia religiosa», en José Martínez Millán y Carlos Javier de Carlos Morales (coords.), La monarquía de Felipe II: la Casa del Rey, Fundación Mapfre, Madrid, 2005, vol. 1, 517-540; Fernando NeGredo DeL CERro, Los predicadores de Felipe IV: corte, intrigas y religión en la España del Siglo de Oro, Madrid, 2006; Juan Carlos Ruiz Souza, «Capillas Reales funerarias catedralicias de Castilla y León: nuevas hipótesis interpretativas de las catedrales de Sevilla, Córdoba y Toledo», Anuario del Departamento de Historia y Teoría del Arte, 18, 2006, 9-30; Leandro Martínez Peñas, El confesor del rey en el Antiguo Régimen, Editorial Complutense, Madrid, 2007; Paolo Broggio, La teologia e la politica: controversie dottrinali, Curia romana e monarchia spagnola tra Cinque e Seicento, L. S. OlsChKI, Firenze, 2009 y Ofelia ReY CASTElaO, «Las relaciones entre la monarquía y la Iglesia en el siglo xviII: ¿la evolución de un modelo europeo?» en ANNe Dubet y José JAVIER RUIz IBÁÑ̃Ez (coords.), Las monarquías española y francesa (siglos XVI-XVIII): ¿dos modelos políticos?, Casa de Velázquez, Madrid, 2010, 201-212. 
Estos vínculos tan estrechos se fomentaron, en gran medida, a través de las visitas y estancias realizadas por los prelados y dignidades capitulares en Madrid. Allí solían encontrar un ambiente muy familiar, pues era frecuente la presencia de miembros de la nobleza cortesana ocupando estos puestos destacados de la Iglesia secular. Los nobles ofrecían a estos parientes eclesiásticos sus casas para las temporadas madrileñas. A ello debemos de sumar la residencia en Madrid de los agentes de los diferentes cabildos catedralicios, lo que facilitó aún más los contactos. Con frecuencia, obispos y deanes imploraron ante la Corona la consecución de los medios necesarios para llevar a cabo las obras arquitectónicas de sus catedrales, en muchos casos, caracterizadas por su lentitud e incluso con interrupciones de amplios periodos cronológicos. Estas súplicas se tradujeron en el envío de limosnas y, más frecuentemente, en la aplicación de exenciones fiscales que revirtieron en el desahogo de las Fábricas catedralicias. Aunque tampoco podemos dejar de lado que en determinados momentos la petición de socorro económico fue a la inversa, siendo solicitado por la Corona, especialmente durante la guerra de Sucesión.

Particularmente los obispos, aunque también algunas dignidades capitulares, desempeñaron además altos cargos de la administración del Estado. De esta forma, tuvieron que establecer su residencia en Madrid, o en determinados casos, hacer más continuas sus estancias en las capital. Su faceta de hombres de Estado favoreció un mejor conocimiento de los talleres artísticos del momento, lo que unido al incremento de réditos que suponía el desarrollo de estas actividades, en paralelo a los producidos por sus oficios religiosos, supuso un aliciente más para la promoción de las artes.

Obispos y miembros de los cabildos también aprovecharon sus contactos en Madrid para favorecer el intercambio de obra de arte y artistas, así como de pareceres e informes sobre las más variadas cuestiones, particularmente las arquitectónicas. Esta práctica quedó materializada en varios aspectos. Por un lado destacó la solicitud por parte de las diferentes diócesis de artistas afincados en la corte que afrontaran los más diversos encargos. Arquitectos, pintores, escultores, plateros, etc. que contaban con el excelente aval de su «alta procedencia y consideración», hecho que se acentuaría a partir de la creación de la Academia de San Fernando. Asimismo asistimos al movimiento inverso, es decir, maestros que eran enviados desde las distintas diócesis a Madrid para que completaran su formación o atendieran encargos concretos como la realización de copias de originales custodiados en espacios tan privilegiados como las colecciones reales.

A este intercambio de personas debemos sumar el de obras de arte. Un tráfico que estuvo abierto a todo tipo de manifestación artística, no solo las consideradas «artes mayores», sino también y de manera muy significativa a las artes suntuarias, convirtiendo Madrid en un centro de producción de primer nivel. 
El pRincipal motivo de SÚplica a Madrid y a Roma: las fábricas CATEDRALICIAS

Uno de los objetivos prioritarios de las relaciones Iglesia-Estado durante el Antiguo Régimen fue el de la financiación de las catedrales, máximo exponente de la arquitectura religiosa. Para ello entraban en juego la consecución de una serie de exenciones fiscales y liberaciones de rentas percibidas por la Corona. Buena parte de las biografías episcopales destacaron los viajes y misivas a Madrid, y en determinados casos a Roma, para allanar el camino en aras de la conquista de los fines previstos.

Fue el caso de don Baltasar de Moscoso y Sandoval, obispo de Jaén (16191646) y arzobispo de Toledo (1646-1665). El cardenal de Santa Cruz en Jerusalén era hijo del VI conde de Altamira, don Lope de Moscoso Osorio, caballero de Santiago y caballerizo mayor de la reina Margarita, y de doña Leonor de Sandoval y Rojas. Sus abuelos paternos eran don Rodrigo de Moscoso Osorio y doña Isabel de Castro, hija del conde de Lemos; mientras que entre los maternos se encontraban don Francisco de Sandoval y Rojas, IV marqués de Denia y doña Isabel de Borja, hija del IV duque de Gandía, futuro san Francisco de Borja. Entre tan ilustres ascendientes no podemos olvidar a dos de sus tíos: don Francisco de Sandoval y Rojas, duque de Lerma y, el que también fuera obispo de Jaén y arzobispo de Toledo, don Bernardo de Sandoval y Rojas. ${ }^{2}$

La fluida relación que don Baltasar de Moscoso tuvo con Felipe III se hizo más intensa con Felipe IV, destacando un momento muy especial como fue la visita del rey a Jaén en 1624, en la que el obispo actuó como verdadero cicerone, mostrando al monarca, entre otros tesoros, la más preciada reliquia de la diócesis, la Santa Faz. ${ }^{3}$ Por deseo del rey, Moscoso desempeñaría oficios como el de canciller de Castilla y consejero de Estado. Años después, como arzobispo de Toledo, oficiaría buena parte de las ceremonias más importantes de la Corona, por ejemplo, los esponsales de Felipe IV con Mariana de Austria y las exequias de algunos de los miembros de la familia real. Asimismo, sobre él recaería buena parte de la atención espiritual del rey, especialmente durante sus enfermedades. ${ }^{4}$ Además alentó la institución de devociones y celebraciones promovidas por el Rey Planeta, como la del Patrocinio, en el segundo domingo de noviembre, que en Jaén sería dotada por el que fuera su sucesor en el episcopado, don Fernando de Andrade y Castro (1648-1664). ${ }^{5}$ En este contexto, también tenemos que destacar sus contactos con importantes mecenas y

2. Jesús María, Fray A. De, Don Baltasar de Moscoso i Sandoval Presbytero Cardenal de la S. I. R. del título de Santa Cruz en Ierusalem, Bernardo de Villa-Diego, Madrid, 1680, 3. Honró a su bisabuelo san Francisco de Borja con las grandes celebraciones que tuvieron lugar en la catedral de Baeza, Ibídem, 301304.

3. Ibídem, 296-297.

4. Ibídem, 1352. Ex officio miembro del Consejo de Regencia instituido en el testamento de Felipe IV.

5. Ibídem, 2036. 


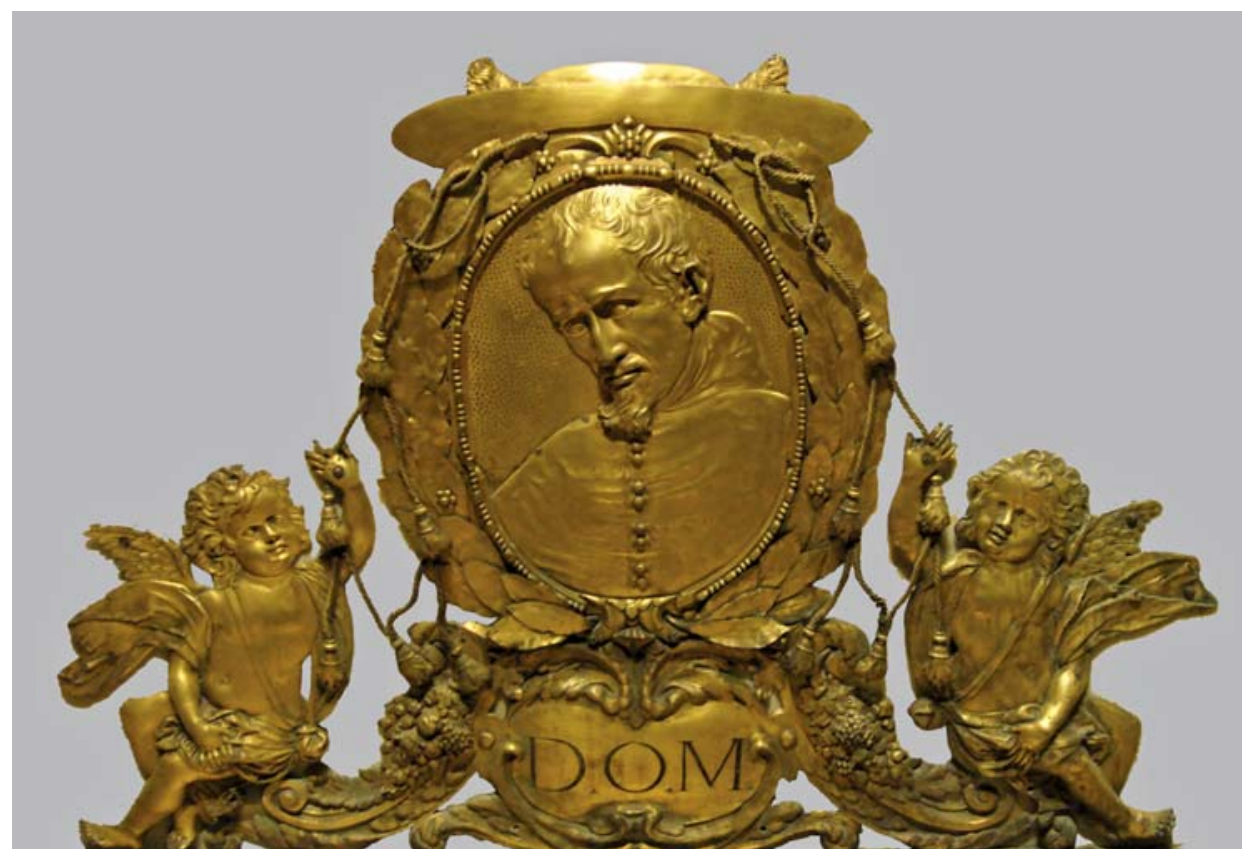

Fig. 1. Virgilio Fanelli y Francisco Salinas, Sepulcro del cardenal Moscoso y Sandoval, 1665, capilla de la Descensión, catedral de Toledo

coleccionistas que, con toda certeza, influyeron en la definición de su gusto. Entre ellos destacarían personajes como don Manuel de Fonseca y Zúñiga, VI conde de Monterrey, embajador ante Santa Sede y Virrey de Nápoles, que le hospedaría en Roma y en la capital del virreinato durante su periplo italiano; o don Luis de Haro, VI marqués del Carpio, que visitaría al cardenal en Jaén antes de que partiese hacia su nuevo oficio en la sede primada. ${ }^{6}$ Los puestos desempeñados por designación regia y las embajadas a Roma por diferentes asuntos constituyen una prueba irrefutable de la confianza que depositó en él Felipe IV.

Con estas cartas de presentación, no es de extrañar la intensa labor de promoción artística que desarrolló en las dos diócesis que gobernó. En la de Jaén, entre las muchas obras que acometió, resplandece la continuación de la fábrica catedralicia. En esta empresa hizo gala de sus dotes diplomáticas enfocadas hacia Madrid y Roma para conseguir los medios suficientes que le permitieran poner en marcha una construcción que llevaba paralizada desde finales del Quinientos, entre otros aspectos por la inoperancia de las fuentes de financiación existentes. ${ }^{7}$

6. Ibidem, 1035.

7. Una vez que había puesto en marcha las constituciones del Sínodo celebrado en 1624 «convirtió su particular cuidado a continuar la fábrica de la catedral, que (habiendo comenzado) por falta de medios, tenía más de setenta años de suspensión, aunque amenazando ruina el crucero de la antigua, no sin bocas; bien que mudamente, clamaban por la Nueva traza del insigne Maestro Valdelvira» Ibídem, 654. 
En su afán de «fabricarle a Dios un insigne templo, donde fuese magníficamente alabado», comenzó a mover los hilos de una maquinaria que él conocía a la perfección. La embajada en Roma que realizó junto a los cardenales Borja y Espínola a petición de Felipe IV entre 1630-1633, jugó un papel trascendental en el ánimo del obispo. Aunque el principal fin de la misma no se consiguió -hacer partícipe al papa en la guerra de los Treinta Años contra los protestantes-,- 8 sí en cambio le permitió tener un contacto directo con la corte romana, pues entre otros aspectos recibió el capelo de manos de Urbano VIII. Don Baltasar se implicaría activamente en la aportación de recursos tanto procedentes de los réditos que proporcionaba su propia dignidad episcopal, como de los pertenecientes a la mesa capitular y a la Fábrica del templo. A ellos uniría los de otras instituciones (las parroquiales diocesanas) e incluso hasta determinadas rentas eclesiásticas. Para la obtención de los permisos necesarios tuvo que solicitar el consentimiento de Felipe IV, por encontrarse bajo los derechos de patronato, y del papa Urbano VIII «diligenciándolas i costeándolas con tan grande fervor D. Baltasar que habiéndose comenzado a tratar el punto al principio deste año de XXXV, a fin dél (...) estaba derribada la capilla mayor [la primitiva de la catedral gótica] i comenzada la nueva». ${ }^{9}$ La dignidad episcopal, primero en su persona y después en sus sucesores, quedó cargada durante veinte años con una pensión de dos mil ducados anuales. Asimismo obligó a la mesa capitular con el pago de mil quinientos ducados al año, a los que se sumarían los quinientos aportados por la Fábrica. A la construcción de la nueva catedral se destinarían igualmente las octavas partes de las Fábricas parroquiales y las rentas generadas durante las vacantes de prebendas y beneficios eclesiásticos.

Cuando estaban a punto de cumplirse los veinte años de las prerrogativas y habiendo dejado Moscoso y Sandoval el gobierno de la diócesis de Jaén, el cabildo de la catedral le solicitó su prorrogación. El cardenal lo consiguió con consentimiento del rey y del papa aunque

Tuvo graves dificultades i pidieron de Roma muchos informes i trazas de la Fábrica, i del Estado en que se hallaba, con que fue menester largo tiempo más perseverando D. Baltasar en las instancias i súplicas consiguió el año de DCLV se le continuase la concesión por otros veinte i luego que recibió la Gracia, la remitió a aquella Iglesia, que hizo la estimación debida de su cuidado i su fineza, a que siempre correspondieron con recíprocos indicios de amor i reverencia $[\ldots] \cdot{ }^{10}$

8. Gonzálvez, R., «Moscoso y Sandoval, Baltasar», Quintín Aldea Vaquero (dir.), Diccionario de historia eclesiástica de España, vol. III, Consejo Superior de Investigaciones Científicas, Madrid, $1973,1746$. En 1634 el rey volvía a pedir a Moscoso que fuera a Roma: EnCARnACión Sánchez García, Imprenta y cultura en la Nápoles virreinal: los signos de la presencia española, Alinea Editrice, Florencia, 2007, 143-144.

9. Jesús María, Fray A. De, Don Baltasar de Moscoso i Sandoval..., 655 y Pedro A. Galera Andreu, La catedral de Jaén, Everest, León, 1983, 11.

10. Jesús María, Fray A. De, Don Baltasar de Moscoso i Sandoval..., 1354-1355. Al año siguiente recibía la canonjía de magistral de la catedral de Jaén el doctor don Juan Rubiños, del salmantino Colegio Mayor de San Salvador de Oviedo del que también procedía Moscoso. 
La efectividad de estas gracias quedaría constatada en su larga vigencia, hasta la segunda mitad del siglo XVIII, ${ }^{11}$ momento en el que algunas, como la referida a las vacantes, dejaron de generar ingresos para el fin previsto. En cuanto a la pensión que se aplicó sobre los obispos, los sucesores de Moscoso, por lo general, aceptaron la imposición, aunque algunos generaron graves trastornos por su incumplimiento. ${ }^{12}$

Como podemos comprobar la Corona se convirtió en un punto de referencia para la consecución de los anhelos constructivos de los obispos en sus diócesis. ${ }^{13}$ Se materializaban así unas intensas relaciones que adquirían una mayor entidad en aquellas instituciones que se encontraban bajo el patronato real, por ejemplo las catedrales de Granada y Guadix. La metropolitana granadina se terminaba en 1704, tras su comienzo en 1528, gracias, en gran parte, a las ayudas de la monarquía. ${ }^{14}$ En la catedral accitana, el apoyo económico y espiritual que ofreció el cabildo a Felipe de Anjou, al igual que el resto de catedrales andaluzas, tuvo una rápida contraprestación una vez terminada la contienda. Tras la firma del Tratado de Utrecht en 1713, el monarca, mediante Real Cédula, atendiendo a la previa petición del cabildo, concedía la octava

11. «Propuesta del Sr. Deán sobre la carta convocatoria a los SS. Residentes en Baeza» «(...) para que concurriesen en esta a tratar de los medios de sostener la Fábrica de la obra nueva para continuar sus obras que están pendientes (...) y como ninguna destas obras puede excusar el Cabildo, como ni las que faltan por ser el complemento de la Yglesia y por otra parte estar para expirar la Bula de la Gracia de Vacantes que ha sido uno de los fondos con que se ha proseguido la obra nueva que en lo futuro se considera ya de poquísima utilidad por haber variado sustancialmente con el motivo del concordato que hace las vacantes brevísimas y ser preciso se establezcan otros más efectivos como los que acordaron en tiempo del Illmo. Sr. Cardenal Sandoval, obispo que fue deste obispado, según contiene el auto capitular de 3 de febrero de 1634. Para efecto de tratar y resolver los medios con que de aquí en adelante se hayan de proseguir las obras que van relacionadas y demás que convenga a la consecución de un fin que es tan de nuestra obligación, honor y conciencia y haberse dado comisión al Sr. Doctoral para que ordenase la mencionada carta convocatoria mediante ser esta especie de grave consideración y necesitar de inspeccionar los medios de que hasta aquí se han valido nuestros antecesores para poner la Yglesia en el estado en que hoy se halla...» Acta Capitular (AC.) 22 de enero de 1760, Capitular, caja 87, Archivo Histórico Diocesano de Jaén (AHDJ).

12. Especialmente significativo fue el caso del obispo don Antonio Brizuela y Salamanca. Sobre este aspecto: JuAn Higueras Maldonado, «Antonio Brizuela y Salamanca (1693-1708) y la construcción de la catedral de Jaén», Boletín del Instituto de Estudios Giennenses, 194, 2006, 181-188.

13. Entre los muchos ejemplos con los que contamos podemos destacar también el del obispo de Córdoba don Francisco de Reinoso (1597-1601). Bien conectado con la corte y especialmente con la pontificia, consiguió los medios suficientes para acabar la catedral de Córdoba, tomando la empresa como algo personal «Para su firmeza y seguridad, yo llamaré maestros de gran experiencia que reparen las quiebras y hagan nuevas traças. En lo que falta de los gastos, nadie tema, que por mi cuenta han de estar, y desde luego para poner la primera mano ofrezco dos mil ducados y los consigno cada año para todo el tiempo que durare la obra, espero en la Magestad Divina que no ha de faltar, Dios la començó, Dios la acabará». De inmediato ponía en marcha las obras, llamando a Diego de Praves, maestro mayor de Valladolid, que daría las directrices para la consecución de las mismas. Gregorio de Alfaro, Vida del Illustrísimo Sr. D. Francisco de Reynosso, Obispo de Córdoba, donde se pone la de Gerónimo de Reynosso su sobrino Canónigo de la Iglesia de Palencia, Francisco Fernández de Córdoba, Valladolid, 1617, 16-17 y 34.

14. En relación con los aspectos de financiación del templo: Miguel Luis López-GuAdalupe MuÑoz, «El Cabildo en la Edad Moderna: erección, composición y rentas», en LÁzARo Gila Medina (coord.), El Libro de la Catedral de Granada, vol. I, Granada, Cabildo Metropolitano, 2005, 39-67 y sobre la colaboración de la Corona en la etapa final de las obras: LÁzAro GiLA MEDINA, «La última etapa constructiva: de 1650 a 1704», en Lázaro Gila Medina (coord.), El Libro de la Catedral de Granada, vol. i, Granada, Cabildo Metropolitano, 2005,171-208. 
parte de los diezmos recaudados en el obispado para impulsar las ralentizadas obras de su templo mayor. ${ }^{15}$

Algo similar ocurrió en la catedral de Jaén, donde el cabildo también había respondido positivamente a la solicitud de ayuda lanzada por la Corona borbónica. Al terminar la guerra, los capitulares giennenses elevaban una súplica al rey para conseguir medios suficientes con los que proseguir las obras del templo. Para ello aprovechaban la figura de su deán, don Iñigo Manuel Fernández de Córdoba, caballero de Alcántara y hermano del conde de Torralba, que nada más llegar el duque de Anjou a Madrid le había mostrado su lealtad y expresado un exquisito cuidado y esmero por todas las celebraciones que solicitó el nuevo monarca: ${ }^{16}$ proclamación, casamiento, descendencia y los acontecimientos bélicos de Almansa o Brihuega. ${ }^{17}$ Como respuesta a la petición cursada por el deán Manuel, a la catedral de Jaén le fue concedida la gracia de la aplicación de las vacantes de las rentas que cobraba el rey en el obispado. Unos años más tarde, en 1728, se volvía a presentar esta súplica, a la que de nuevo se daba respuesta positiva, lo que permitió, junto a otras gracias, concluir la fábrica material del templo cuando comenzaban a fallar los mecanismos de financiación que un siglo antes había puesto en marcha el cardenal Moscoso y Sandoval. ${ }^{18}$

\section{LA CORTE: CANTERA DE LOS «MEJORES ARTÍFICES» Y REFERENCIA OBLIGADA PARA LOS ARTISTAS DE LAS DISTINTAS DIÓCESIS}

En todas estas acciones las catedrales supieron aprovechar la presencia de sus agentes en Madrid que, junto a los contactos ya vistos, hicieron mucho más fluidas las relaciones con la monarquía. ${ }^{19}$ Estos singulares «embajadores» facilitaron los tratos entre las diócesis a las que representaban y los artistas que trabajaban en la Corte, al tiempo que abrieron el camino a aquellos paisanos que pretendían formarse o trabajar en Madrid.

En el caso de Jaén y Toledo, estas prácticas, enmarcadas en los gobiernos del cardenal Moscoso y Sandoval, facilitaron el intercambio de maestros entre

15. PÉrez López, S., «Guadix y su Catedral, tres siglos de historia. De la incorporación de la ciudad a la Corona de Castilla a la crisis del Antiguo Régimen», en Antonio Fajardo Ruiz (coord.), La Catedral de Guadix, Magna Splendore, Mouliaá Map, Granada, 2007, 93-101.

16. «El Sr. Deán da cuenta de aver B. L. M. al Sr. D. Felipe Quinto», AC. 14 de junio de 1701, Capitular, AHDJ.

17. Al tiempo que se celebraban las honras por Carlos II, el cabildo preparaba el Te Deum por la llegada del duque de Anjou y la bendición del pendón. De este modo se desarrollaría la aclamación del nuevo rey y las demostraciones públicas por su llegada a Madrid: AC. 28 de noviembre de 1700, 2 y 5 de diciembre de 1700 y 21 de febrero de 1701, Capitular, caja 54, AHDJ.

18. AC. 4 de julio de 1713, Capitular, caja 61, ADHJ. «Que se haga una representación al Rey nro. Sr.» 10 de abril de 1728, Capitular, caja 68, ADHJ.

19. Precisamente fue el cardenal Moscoso y Sandoval quien animó al resto de diócesis a que contaran con la figura del agente o procurador en las cortes de Madrid y Roma, Fray Antonio de Jesús María, Don Baltasar de Moscoso i Sandoval..., 1679. 
la capital y las dos diócesis que gobernó e incluso posibilitaron la labor de algunos artífices en espacios reservados a unos pocos privilegiados. En Jaén, en el contexto antes analizado de la reactivación de las obras de la catedral, su biógrafo, el carmelita fray Antonio de Jesús María nos dice que «Para la elección de la planta, que se debía seguir, había traído de Madrid, de Toledo i de toda la Andalucía a Iaén los arquitectos más famosos, que se hallaban. Túvolos muchos días en su casa, regalándolos, i festejándolos con grande galantería: i después de haver tomado resolución, los despidió mui bien satisfechos y agradecidos». ${ }^{20}$

Unos años más tarde, cuando en 1668 Eufrasio López de Rojas se hiciera cargo de la maestría mayor del templo y comenzara la construcción de la fachada, el cabildo giennense volvería a recurrir a Toledo. Aunque el cardenal Moscoso ya había muerto, los capitulares aprovecharon su buena relación con la sede primada para solicitar la presencia del entonces maestro mayor de la catedral toledana, Bartolomé de Zumbigo y Salcedo para que dictaminase sobre el proceder de la obra. El canónigo Pedro de Sahagún -el que fuera secretario y hombre de confianza de Moscoso- estaba al frente de la comisión encargada de elegir el modelo más adecuado de entre los presentados por López de Rojas. ${ }^{21}$

Como podemos comprobar, Moscoso ejerció una gran influencia sobre Jaén, incluso siendo arzobispo de Toledo, y su mediación quedaría patente en tareas tan complicadas como la consecución de los permisos necesarios para que el pintor Sebastián Martínez Domedel (ca. 1615-1667) pudiera copiar originales del monasterio de San Lorenzo de El Escorial. El cardenal conocía y admiraba esta residencia regia, entre otras cuestiones, porque allí oficiaría diversas ceremonias para la familia real, por ejemplo las exequias por el príncipe Baltasar Carlos. ${ }^{22}$ De hecho, don Baltasar debió influir considerablemente en el programa iconográfico del retablo mayor y en el estilo de las pinturas elegidas.

El encargo que tenía que cumplir el pintor giennense le llegó por parte del cabildo de la catedral que le pidió tomar «las copias de las pinturas que en Madrid parecieren más apropósito y las trayga». ${ }^{23}$ Buena parte de estas copias estarían destinadas a conformar el programa pictórico del retablo mayor de la catedral de Jaén, indicándosele que las hiciera con un reducido tamaño para facilitar su transporte y su más rápida ejecución. Una vez en Jaén, el cabildo

20. Ibídem, 657.

21. «Que se escriba venga el Maestro Mayor de Toledo», AC. 21 de enero de 1668, Capitular, caja 41, AHDJ. Unos meses más tarde: «Ynforme de el mro. mayor de Toledo y se le den de ayuda de costa 400 ducados» AC. 2 de mayo de 1668, Capitular, caja 41, AHDJ. Todo el proceso de construcción de la fachada y las referencias a las citadas actas capitulares: Pedro A. Galera Andreu, Arquitectura de los siglos XVII y XVIII en Jaén, Caja de Ahorros de Granada, Granada, 1979, 164-168 y «La fachada de la catedral de Jaén y la consolidación de la "arquitectura efímera"», N. Marín, A. Gallego Morel y A. Soria Olmedo (coords.), Estudios sobre Literatura y Arte dedicados al profesor Emilio Orozco Díaz, Universidad, Granada, 1979, 523-531.

22. Jesús María, Fray A. De, Don Baltasar de Moscoso i Sandoval..., 1178 y 1179.

23. AC. 14 de octubre de 1661, Capitular, caja 40, AHDJ. 


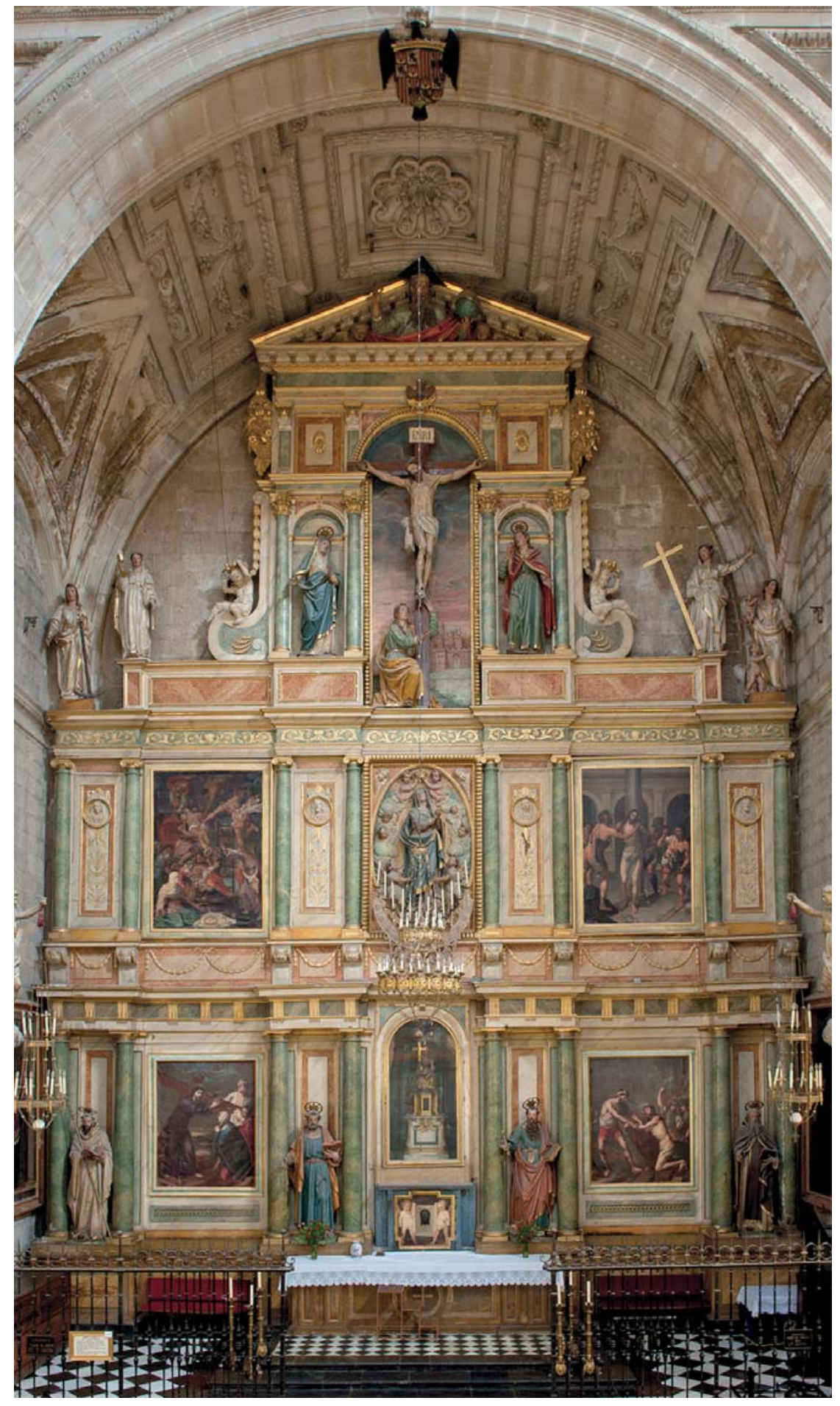

Fig. 2. Francisco Y Sebastián Solís, 1602-1605 (remodelado en 1821), Retablo Mayor, capilla Mayor, catedral de Jaén 
seleccionaría las más apropiadas para que el pintor las desarrollase a una escala mayor. A Martínez se le había encargado el refresco de esta importante pieza de la catedral, una obra que se había realizado a principios del siglo XviI por los hermanos Francisco y Sebastián de Solís a instancias del obispo don Sancho Dávila (1600-1615). Con motivo del derribo de la capilla mayor de la vieja catedral en 1635, el retablo fue desmontado y adaptado posteriormente en la nueva capilla mayor (ca. 1658-1660). ${ }^{24}$ Moscoso y Sandoval ya no era obispo de Jaén, pero sin duda el cabildo y su sucesor en la sede giennense, su primo don Fernando de Andrade y Castro, ${ }^{25}$ obispo de Jaén y arzobispo de Palermo, serían fieles continuadores de sus proyectos, entre ellos, el más importante, las obras de la catedral. ${ }^{26}$

En los meses previos a la consagración del templo -octubre de 1660- se encargaba al artista giennense la realización de la pintura para decorar la tapa del nicho que acogería al Santo Rostro «obra de Sebastián Martínez, que justamente merece las aclamaciones deste siglo». ${ }^{27}$ Pero no sería hasta agosto de 1661 cuando el cabildo comenzara a realizar la serie de gestiones necesarias para conseguir las pertinentes licencias reales que permitieran enviar a Sebastián Martínez a El Escorial. Para ello los capitulares aprovecharon, como hemos visto, la mediación del entonces obispo y de su antecesor. Precisamente sería un sobrino de este último, don Vicente Pimentel y Moscoso, ${ }^{28}$ caballero de Santiago y fiscal en el Consejo de Aragón, el que jugara un papel determinante en esta decisión. ${ }^{29}$ Junto a ellos el ya citado canónigo don Pedro de Sahagún y el agente del cabildo en Madrid, don Alonso Ramírez de Prado.

24. A lo largo de los siglos XViI y xviıi sufriría algunas intervenciones, sobre todo en referencia a los espacios destinados a custodiar al Santo Rostro y a la Virgen de la Antigua. Pero sería en 1821 cuando, entre otros factores, debido a las fuertes críticas que sobre esta pieza vertieran académicos como Ponz y Ventura Rodríguez, se llevara a cabo una intervención más drástica que daría como resultado el estado actual del retablo. Esta obra supuso grandes cambios tanto en su estructura como en su programa pictórico y escultórico. En referencia a esta intervención: Arturo Aragón Moriana, «Aportaciones para el estudio del retablo de la capilla mayor de la S. I. Catedral de Jaén», Boletín del Instituto de Estudios Giennenses, 182, 2002, 43-78.

25. Este dato nos lo aporta Fray Antonio de Jesús María, Don Baltasar de Moscoso i Sandoval..., 1437.

26. Durante su gobierno mantuvo a buena parte de la curia de Moscoso, como don Gabriel de Ledesma, don Francisco de Mendoza, don Pedro de Sahagún y los hermanos Juan Bautista Casela y Domingo Pasano.

27. Núñez de Sotomayor, J., Descripción Panegyrica de las insignes fiestas que la S. Iglesia de Catedral de Iaén celebró en la translación del SS. Sacramento a su nuevo y sumptuoso templo, Mateo López Hidalgo, Málaga, 1661, 27-29 y AC. 28 de septiembre de 1660, Capitular, caja 39, AHDJ.

28. Jesús María, Fray A. De, Don Baltasar de Moscoso i Sandoval..., 2161. La información que nos aporta Fray Antonio es confusa ya que habla de un sobrino del cardenal, hijo de su hermana, la marquesa de Távara, también llamado Vicente, al que, con otro hermano, Lope, y otros dos sobrinos hijos de su hermano el marqués de Villanueva del Fresno, crió don Baltasar en su casa. A los dos primeros les costeó sus estudios en Salamanca, concretamente en el Colegio de San Salvador de Oviedo, donde Moscoso había estudiado. Pero nos dice que don Vicente murió en 1652: «Hasta averlos acomodado de renta competente los sustentaba el cardenal, cuidando mucho de que tuviesen ayos, maestros y criados, como convenía para su mejor educación, pero luego que los fue acomodando de prebendas i beneficios, cada uno se sustentaba...» Ibídem, 659-665.

29. AC., 3 de agosto de 1661, Capitular, caja 40, AHDJ. 


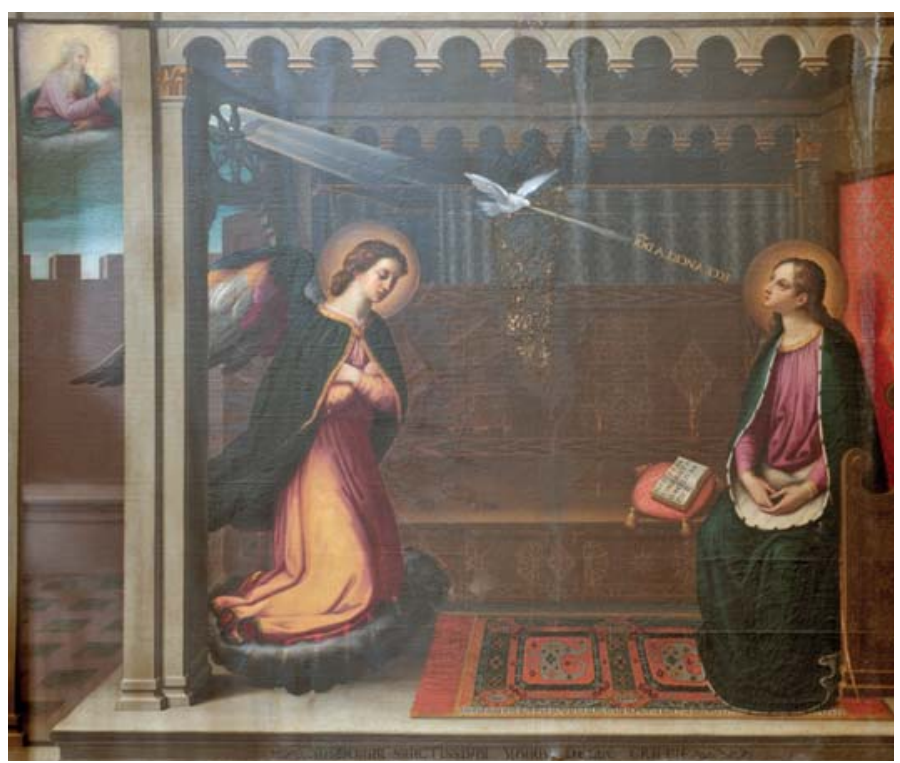

Fig. 3. Sebastián Martínez, Anunciación, (copia de la Annunziata de Alessandro Allori), 1660-1662, 334 x 423 cm, Capilla Mayor, catedral de Jaén

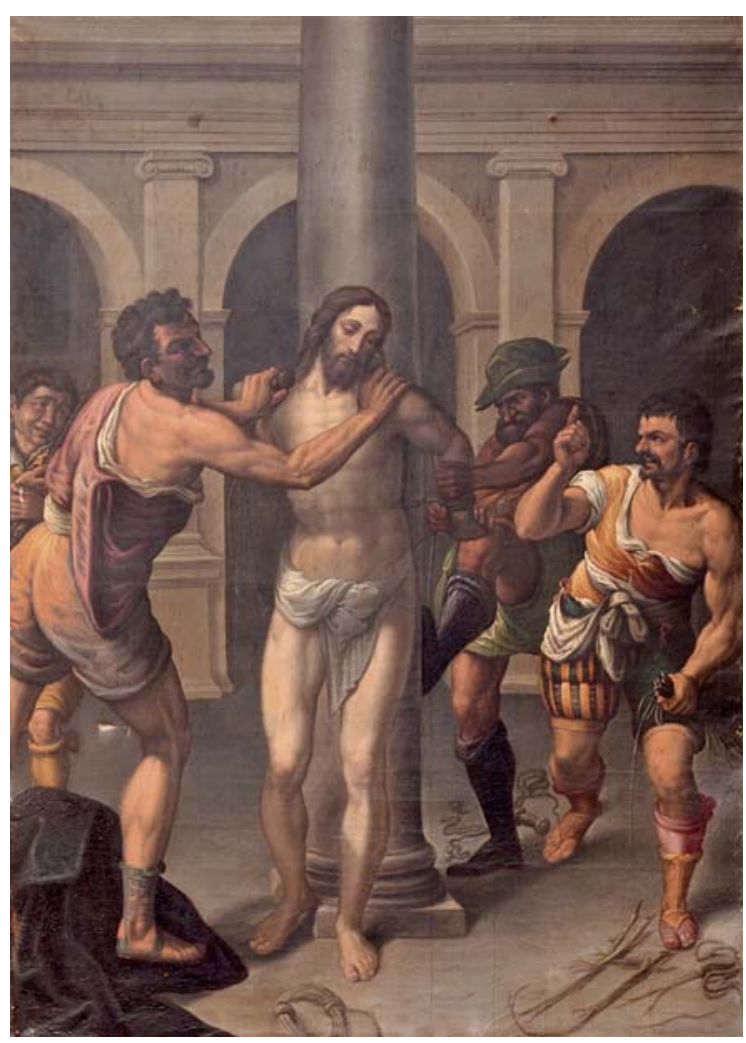

Fig. 4. Sebastián Martínez, Cristo atado a la columna, (copia de Juan Fernández de Navarrete), 1660-1662, 232 x 192 cm, Capilla Mayor, catedral de Jaén 
La fecha era muy apropiada para tal fin, puesto que la familia real pasaba los meses más fríos en el Alcázar, dejando por tanto El Escorial. Sin embargo, desconocemos el motivo que condujo a que en febrero de 1662 se volviera a pedir licencia a Felipe IV para que Martínez trabajase en el monasterio de san Lorenzo. Entre las posibles causas podríamos barajar la ausencia de respuesta a la primera petición, o el tratarse de un nuevo encargo o, incluso, la demora del pintor, bien en llegar a Madrid o bien en ejecutar lo encomendado. De ser esto último, obligaría a pedir una nueva licencia, dada la proximidad de la llegada de la familia real a San Lorenzo. ${ }^{30}$ Lo cierto es que estos datos y el que en agosto de 1662 se realizase el traslado definitivo del Santo Rostro a su nicho del retablo mayor, nos indican que pudo ser entonces cuando se diera por terminada la obra. ${ }^{31}$

Para ilustrar con otro de los muchos ejemplos que muestran la preocupación que Moscoso y Sandoval manifestó por la diócesis de Jaén, aun cuando estaba fuera de ella, haremos referencia a uno de los regalos que envió a la catedral de Baeza. En concreto, se trataba de una custodia de plata obra «del insigne Merino», que había comprado personalmente, aunque no dejara claro dónde, pues solo decía que era sabedor de «que se vendía». Con ella tenemos una excelente muestra de «como el amor al Obispado de Jaén fue el primero en el religioso pecho de D. Baltasar», más aún cuando era conocedor del robo de la primitiva custodia de la catedral baezana. ${ }^{32}$

Su política de promoción artística continuó en Toledo. Allí alentó empresas de notable magnitud, como la finalización de la Capilla de las Reliquias y de modo particular el encargo del trono para la Virgen del Sagrario, ${ }^{33}$ patrona de la ciudad. Unas tareas que se enmarcaron en un momento difícil para la Fábrica de la catedral y con las a veces tensas relaciones entre el prelado y el cabildo como telón de fondo. Para llevar a buen término la ejecución del trono de la Virgen, encargó al obrero de la catedral, don Pedro de Inarra, que escribiera a Madrid «para que los mayores artífices hicieren (conformándose con las medidas del sitio en que está la Imagen) varios diseños i después se confiriesen, i se eligiese el que pareciese mejor». El propio cardenal intercedería para que fueran a Toledo los maestros de obras del rey

30. AC., 14 de febrero de 1662, Capitular, caja 40, AHDJ.

31. AC., 8 y 11 de agosto de 1662, Capitular, caja 40, AHDJ.

32. Jesús María, Fray A. De, Don Baltasar de Moscoso i Sandoval...,1388.

33. Sobre las obras del Ochavo y los maestros que intervienen en ellas, especialmente por la labor de decoración llevada a cabo por Zumbigo en tiempos de Moscoso: Elisa BerMEJO, «Bartolomé Zumbigo, arquitecto del siglo Xviı», Archivo Español de Arte, 27, 1954, 297-298 y FERnANDo MArías, La arquitectura del Renacimiento en Toledo (1541-1631), III, Instituto Provincial de Investigaciones y Estudios Toledanos, Madrid, 1986, 117 y 207-210 y «Alonso Cano y la columna salomónica», Figuras e imágenes del Barroco: estudios sobre el Barroco Español y sobre la obra de Alonso Cano, Fundación Argentaria, Madrid, 1999, 291 322. Asimismo: Diego SuÁrez Quevedo, La arquitectura barroca en Toledo, Caja de Toledo, Toledo, 1990, 255-257 y más recientemente, aunque en referencia a los aspectos simbólicos, FernANDo LLAMAZARES Rodríguez, «El Templo Primado: receptáculo de reliquias y su significado» en José Carlos Vizuete Mendoza y Julio Martín Sánchez (coords.), Sacra loca toletana. Los espacios sagrados en Toledo, Universidad de Castilla la Mancha, Cuenca, 2008, 289-318. 
[...] i confirieron los rasguños, que habían dibujado el Hermano Francisco Bautista de la Compañía de Jesús, i Pedro de la Torre, insignes arquitectos, i cotejados con otros de don Sebastián de Herrera i Alonso Cano, eminentes en la Pintura i Arquitectura, se eligió el que pareció mejor. Deste mandó don Baltasar abrir lámina i le imprimió [...].

En su tradicional forma de actuar, el cardenal pidió informes en otras provincias así como en Roma y en otros puntos de Italia, lugares que conocía bien, llegando a afirmar que era allí «donde está más valida, que en otras provincias la Pintura y Arquitectura, para que consultados los mejores artífices por el agente de la Dignidad, que entonces despachó a Roma, enviasen sus notas, i, vistas se tomase la última resolución (...)». En agradecimiento a la mediación regia en todas estas acciones, ordenaba poner el retrato del rey debajo de la Virgen «protestándole Patrón de la Santa Iglesia (aunque después se varió esta traza), i haviendo impreso en raso la estampa, se la llevó a su Magestad, que la recibió con especial estimación i aprobó la idea, con que dio una grande calificación a los artífices inventores (...)». Finalmente, se encargaría la ejecución de la obra al florentino Virgilio Fanelli, el Praxíteles Florentín, traído expresamente desde El Escorial. ${ }^{34}$

\section{Entre Madrid y Jaén. Don Agustín Rubín de Ceballos, un ejemplo EXCEPCIONAL DE PROMOCIÓN DE LAS ARTES}

El desempeño de oficios dentro del gobierno del Estado por parte de los prelados contribuyó al aumento considerable de sus ingresos, lo que se tradujo, en determinadas ocasiones, en importantes acciones de promoción de las artes. Así por ejemplo le ocurrió al arzobispo de Zaragoza, don Antonio Ibáñez de la Riva Herrera (1687-1710), que fue presidente del Consejo de Castilla y de la Sala de Millones, y más tarde virrey y capitán general del Reino de Aragón, siendo nombrado inquisidor general por Felipe V. Buena parte

34. En el año 1650 llega a Toledo la lámina hecha por Juan de Noort «Deseoso D. Baltasar de que no solamente se lograse el acierto, con que la inventaron, como diximos, el Hermano Francisco Bautista i Pedro de la Torre...». Fray Antonio de Jesús María, Don Baltasar de Moscoso i Sandoval...,1448 y JuAn Nicolau Castro, «La maqueta del trono de la Virgen del Sagrario de la catedral de Toledo», Boletín de la Real Academia de Bellas Artes de San Fernando, 83, 1996, 271-285. El cardenal hizo numerosas donaciones a la catedral, desde una corona imperial para la Virgen del Sagrario, valorada en siete mil ducados, hasta un juego de doce reposteros de terciopelo carmesí con escudos bordados en oro que habían sido de su tío don Bernardo: Fray Antonio de Jesús María, Don Baltasar de Moscoso i Sandoval..., 1347 y 1348. Otro ejemplo de obispo que facilitó los contactos entre su diócesis y Madrid lo encontramos en la figura de don Alonso Antonio de San Martín. Obispo de Cuenca entre 1681-1705 y supuesto hijo de Felipe IV que, a finales del Seiscientos mediaba para que fueran desde la corte a la catedral conquense arquitectos que solucionaran los problemas de su fábrica. Los elegidos fueron José de Arroyo y José Sopeña: Desiré́ TorRaLBA MESAS, «La catedral de Cuenca como núcleo de recepción de artistas (1680-1750). La figura del arquitecto itinerante durante el Barroco», Las Catedrales Españolas. Fuente de Cultura, Historia y Documentación, Lope Barrientos, Seminario de Cultura, 1, 2008, 377-392. Sobre este prelado: Beatriz García Pueyo, Alonso Antonio de San Martín, Obispo de Oviedo y Cuenca e hijo de Felipe IV, Universidad, Oviedo, 2012. 
de los réditos producidos por estos cargos los destinó a la construcción de la capilla de Santiago en la seo de Zaragoza «que se concluyó este año pasado de 1699 con la primorosa perfección, magnificencia, riqueza y hermosura, que se ve en ella misma que es la más verdadera descripción».35

El obispo de Jaén, Fray Benito Marín (1750-1769), fue presidente de la Real Junta de Única Contribución, elegido para tal efecto por Fernando VI en 1748, por lo que tuvo que residir en Madrid hasta $1755 .{ }^{36}$ Durante su episcopado desarrollaría una amplia labor de promoción de las artes, llegando a costear importantes obras en diferentes parroquias y santuarios de la diócesis, destacando las realizadas en la catedral, donde decoró la capilla de san Benito.

Pero sería uno de sus sucesores en la sede giennense, don Agustín Rubín de Ceballos (1780-1793) el que mejor encarnara esta práctica que tan felices resultados tuvo particularmente para la catedral de Jaén. Su preocupación por el templo mayor se materializó desde el momento de su elección como obispo, pero se potenciaría considerablemente cuando fuera nombrado inquisidor general en 1784. Quizás la ausencia de su sede episcopal, motivada por el cumplimiento de su nuevo oficio en Madrid, le condujo a una mayor atención hacia ella, evitando de este modo las posibles críticas por su falta al principio de residencia. ${ }^{37}$ Por tal razón, envió numerosos presentes y socorrió algunas de sus principales necesidades, primordialmente, las referentes a la decoración de la catedral y a la construcción y ornato de su Sagrario.

El aumento de capital que le supuso tal nombramiento, que se sumaba a sus prebendas como consejero del rey en el Consejo de la Inquisición y caballero de la Orden de Carlos III, posibilitó buena parte de estas acciones. Como él mismo reconociera, vivió sin realizar gastos superfluos y supo administrar admirablemente su patrimonio, invirtiendo sus honorarios como prelado giennense en las obras de su diócesis y reservándose lo obtenido como inquisidor general, de lo que, finalmente, también saldría beneficiada la catedral de Jaén. ${ }^{38}$

35. Hebrera, Fray J. A. De, Vida prodigiosa del Ilustrísimo y Venerable D. Martín García, Obispo de Barcelona (edición de José de Mediavilla), Domingo Gascón y Diego de Larumbe, Zaragoza, 1700, 25.

36. «Comisión para legacía de bienvenida a su Illma.» AC. 12 de septiembre de 1755, Capitular, caja 84, AHDJ.

37. Don Agustín Rubín de Ceballos patrocinó numerosas obras y envió ricos regalos que satisfacían las necesidades cultuales no solo de la catedral de Jaén, con la que fue particularmente generoso, sino también la de Baeza y las colegiales de esta última ciudad y Úbeda, «Relaciones de Diócesis», Congregación del Concilio, Caja 364, fols. 334r-v, Archivio Segreto Vaticano.

38. «Testamento del excm. ${ }^{\circ}$ señor don Agustín Rubín de Ceballos, obispo de Jaén e Ynquisidor General», Protocolo 21.732, fols. 179-182, Archivo Histórico de Protocolos de Madrid: transcrito y publicado por José Luis Barrio Moya, «Las donaciones del obispo don Agustín Rubín de Ceballos a la Catedral de Jaén», Boletín del Instituto de Estudios Giennenses, 179, 2001, 59-67. 
Durante su gobierno regaló magníficas obras como el Relicario de Santa Cecilia o el rico terno blanco para las grandes fiestas de la Dedicación y Corpus Christi que el prelado encargó en los talleres toledanos de Miguel Molero. ${ }^{39}$ Seguramente entre su pontifical se encontraban algunas piezas conservadas en la actualidad en la catedral, que han sido datadas durante el gobierno del prelado y que tienen procedencia madrileña. En concreto, el Reloj de Antonio Molina de la Real Escuela de Madrid o las taraceas de Francesco Abbiati que representan al Niño Jesús y a la Virgen de los Dolores. Ante tan numerosas atenciones, el cabildo le recordaría que:

Le vivirá eternamente agradecido, y pedirá a su Divina Majestad por la salud de S.S. y mayor prosperidad y para acreditarlo desde luego determinaron dichos Sres. que el primer día semidoble se diga una misa solemne votiva con música a Nra. Sra. de la Antigua implorando por su medio el socorro del todo Poderoso para que conserve la vida de S.S. y dé acierto en el servicio de este su obispado y demás asuntos graves que debe a la confianza del monarca $[. . .]^{40}$

Una de las primeras preocupaciones que manifestó Rubín de Ceballos fue la referente al fomento del culto a san Eufrasio, ${ }^{41}$ primer obispo y patrón de la diócesis, gesto muy bien acogido por los capitulares. La devoción al Varón Apostólico había perdido mucha fuerza pese a la reactivación que en determinados gobiernos de sus antecesores se le había conferido, especialmente con Dávila y Toledo, Moscoso y Sandoval y Brizuela y Salamanca.

En primer lugar centralizó el culto al santo en la catedral y ordenó erigirle una capilla y retablo, escogiendo una de las más importantes -tanto por el tamaño como por su carácter privilegiado- la de La Magdalena o Santa María del Pópulo, frontera a la decorada por su antecesor, Fray Benito Marín. ${ }^{42}$ El cabildo aceptó gustoso la propuesta, más aún porque con esta medida

39. Estella Marcos, M. M., La escultura barroca de marfil en España. Las escuelas europeas y las coloniales, Catálogo, Instituto Diego Velázquez, Csic, Madrid, 1984, t. II, 88; Francisco JuAn Martínez RojAs, «Relicario de Santa Cecilia», en vv. AA., La Luz de las Imágenes. La Faz de la Eternidad, Cat. Exp. Alicante, Generalitat Valenciana, Valencia, 2006, 426-429; JuAN CARlos Hernández NúñEz, «Relicario de Santa Cecilia», en Luis F. Martínez Montiel y Fernando Pérez Mulet (coords.), La imagen reflejada. Andalucía, espejo de Europa, Catálogo de Exposición Iglesia de Santa Cruz de Cádiz, 12 de noviembre de 2007- 30 de enero de 2008, Sevilla, Consejería de Cultura, 2007, 222-223; Felipe Serrano ESTRELla, «Las relaciones artísticas entre España e Italia a través de los cabildos catedralicios en la Edad Moderna», en RoSARIO CAMACHO MARTÍNEZ (ed.), Creación artística y mecenazgo en el desarrollo cultural del mediterráneo en la Edad Moderna, Universidad, Málaga, 2011, 343-368 y Néstor, Prieto Jiménez, «Relicario de Santa Cecilia», en Felipe Serrano Estrella (coord..), Splendor Europae. Arte europeo en la diócesis de Jaén, Fundación Caja Rural, Jaén, 2012, 114-117.

40. AC. 22 de octubre de 1788, Capitular, caja 108, AHDJ.

41. De inmediato a su llegada a Jaén, el obispo Rubín situó a sus familiares en el cabildo de la catedral. En primer lugar a su hermano don José Rubín de Ceballos como racionero y, unos meses después, como tesorero en la catedral de Baeza AC. 24 de marzo de 1781 y AC. 18 de septiembre de 1781, Capitular, caja 101, AHDJ. En 1784 Joaquín Alejo Rubín de Ceballos era nombrado canónigo y cuatro años más tarde chantre AC. 29 de noviembre de 1784, Capitular, caja 104 y 19 de septiembre de 1788, Capitular, caja 108, AHDJ.

42. AC. 21 de junio de 1785, Capitular, caja 105, AHDJ. Sobre esta obra: Luz DE UlierTe VÁzQUEz, El retablo en Jaén (1580-1800), Ayuntamiento de Jaén, Madrid, 1986, 261 y 262. 
se adaptaba a los nuevos gustos estilísticos una capilla que, al tiempo de la consagración, había sido decorada reaprovechando algunas piezas de la vieja catedral. Para la ejecución del retablo, el obispo solicitó que fueran los maestros del cabildo Francisco Calvo o Manuel López los que lo trazaran, eso sí, bajo previa aprobación de la Academia de San Fernando.

Finalmente, López sería el encargado de la obra. Su proyecto generó algunos problemas con la Academia, que no veía con buenos ojos los diseños realizados por maestros ajenos a la institución. Pero la mediación del prelado los salvó, haciendo intervenir al académico Juan Adán en la ejecución de las esculturas. ${ }^{43} \mathrm{Al}$ contar con el beneplácito de la institución madrileña, el modelo de retablo se convertiría en el utilizado para algunas de las capillas que se ornaban a finales del XviII, imponiéndose el nuevo gusto neoclásico del que eran adalides tanto el obispo, como el que fuera su mano derecha y deán de la catedral, don José Martínez de Mazas. No es de extrañar que Ponz describiera la obra como «de lo mejor, que modernamente se ha trabajado para ornato de este gran templo». ${ }^{44}$ Para hacer frente a los gastos que traía consigo el retablo, el obispo comenzó a enviar remesas de dinero y el 12 de mayo de 1789 se daba por concluido. ${ }^{45}$ En ese momento, don Agustín regaló un rico ajuar de altar para la capilla y ornamentos sagrados de color rojo, realizados en el taller de Miguel Molero. ${ }^{46}$ Unos meses después remitía cuatro candeleros y una cruz de altar de bronce dorado, con la condición de que solo se utilizarían el día de la fiesta del Santo. ${ }^{47}$

Al tiempo que veía como se concluía esta obra, ya pensaba en la siguiente, el tabernáculo del altar mayor. En esta ocasión aprovechó los excedentes de la Fábrica, que el cabildo pretendía depositar en la Casa de Gremios de Madrid con un interés de un tres por ciento anual. ${ }^{48}$ Tras cuestionar la licitud de esta medida, recordó las carencias de ornamentos que tenía la catedral y la que consideró como «la necesidad más urgente que hay de un tabernáculo para el altar mayor ya sea de piedra de varios mármoles y colores, ya de plata o de bronce dorado a fuego primorosamente ejecutado». La nobleza de los materiales escogidos, daba buena prueba de la calidad y gusto artístico del promotor de la obra, por lo que nuevamente Ponz la ensalzaría como ejemplo que debían seguir el resto de catedrales, ya que era «de los más magníficos del Reyno» y daba una descripción previa a su colocación. ${ }^{49}$

43. AA. CC. 18 y 27 de abril de 1787, Capitular, caja 107, AHDJ.

44. Ponz, A., Viage de España, t. xvi, Viuda de Ibarra, Madrid, 1791, 181.

45. Ac. 7 de enero de 1786, Capitular, caja 106; AA. CC. 18 de abril de 1787 y 6 de octubre de 1787, Capitular, caja 107, AHDJ.

46. Ac. 12 de mayo de 1789, Capitular, caja 109, AHDJ.

47. Ac. 13 de octubre de 1789, Capitular, caja 109, AHDJ.

48. «(...) pagarían en cada un año el tres por ciento de interés y aún admitirían por ahora y hasta mitad de marzo próximo la moneda de vente mrs de oro por el valor que tienen de veinte y un reales y quartillo cada uno; pero que no contestaba dicho Agente a todo de lo que se le había preguntado (...)» AC. 22 de enero de 1788, Capitular, caja 108, AHDJ.

49. Ponz, Viage de España..., 182. 


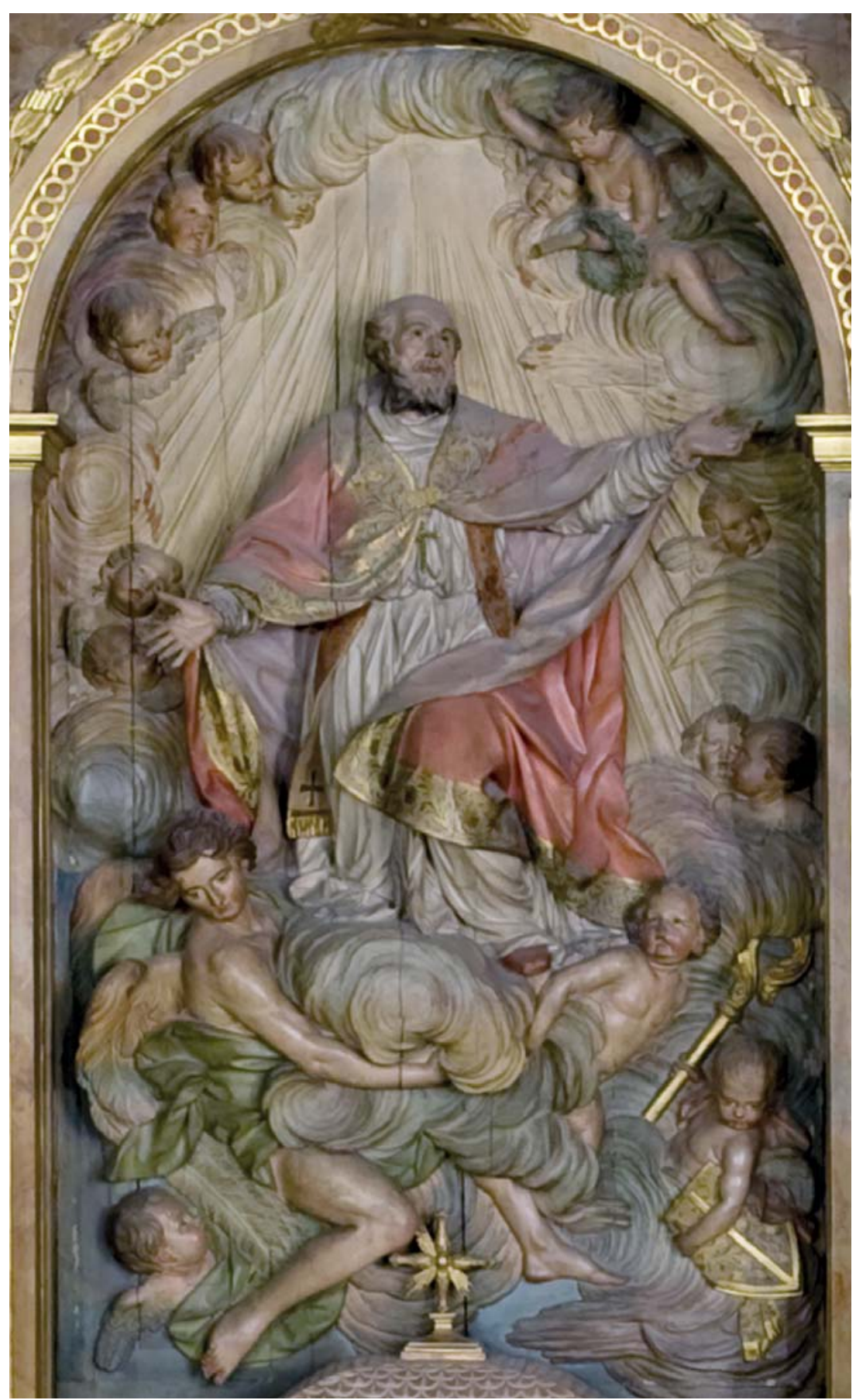

Fig. 5. JuAn AdÁn, Apoteosis de San Eufrasio, 1787, Capilla de san Eufrasio, catedral de Jaén 
Al igual que ocurriera con el retablo de San Eufrasio, el obispo Rubín se volcó en esta empresa y, pese a que el cabildo propuso a sus maestros como ejecutores, él apostó, siguiendo los consejos de Ponz, por académicos como Pedro Arnal, que daría las trazas, los escultores Juan Adán y Alfonso Vergaz, el marmolista Felipe Atichati, y dejó las labores del bronce para el platero Francisco Pecul. ${ }^{50}$ Inflamado en esta determinación y para la ejecución de las esculturas que acompañarían al tabernáculo, compró cuatro bloques de mármol de Carrara, cuyo traslado se vio objetado en el coste y forma por el cabildo. Don Agustín contribuiría económicamente a la ejecución del tabernáculo, aunque no lo vio terminado porque murió en 1793, y hasta el año siguiente no se dio por acabado. Para ello, en su testamento indicó que además del dinero procedente de su oficio como obispo de Jaén, se aplicase también lo que había ganado como inquisidor general:

[...] que en la Santa Yglesia de Jaén se está construyendo [...] a expensas de la Fábrica y rentas de la Mitra que obtengo, el cual es mi voluntad se continúe en la misma forma a cuio fin el dinero existente que tengo en el cajón que está en mi despacho y me corresponde por mi empleo de Ynquisidor general, sin que tenga la menor conexión con las rentas del Obispado, se aplicara enteramente a la continuación de la dicha obra, la qual deseo se perfeccione. ${ }^{51}$

Otro maestro de la corte que el obispo Rubín de Ceballos puso en contacto con Jaén fue Mariano Salvador Maella (1739-1819). A él se le encargarían la Sagrada Familia del trascoro de la catedral y la Asunción de la Virgen para el Sagrario. El pintor valenciano se encontraba en un momento brillante de su trayectoria profesional, materializado en significativos encargos al servicio de la Corona. En tal elección fueron determinantes los criterios de Ponz y particularmente los del entonces maestro mayor del Sagrario, el académico don Manuel Martín Rodríguez. Para conseguir que Maella pudiera atender las obras para la catedral de Jaén, el obispo tuvo que pedir licencia a Carlos IV que la concedería a través del marqués de Bajamar el 4 de julio de 1792.

En un principio solo se planteó encargarle el lienzo del altar mayor del Sagrario, que se dedicaría a la Institución de la Eucaristía. ${ }^{52}$ Diversos problemas motivaron un cambio de planes, tanto en el momento de la ejecución de la obra como en su iconografía. Es por ello que se le encomendará a Maella la realización de la Sagrada Familia para el trascoro. En 1792 ya estaba acabada tal

50. AA. CC. 14 y 21 de julio de 1789 y 7 de agosto de 1789, Capitular, caja 109, AHDJ.

51. BARRIO, «Las donaciones del obispo...», 65-67. La cantidad resultó insuficiente y el cabildo tuvo que hacer frente a una parte de los gastos. Los capitulares llegaron a recurrir a los familiares del obispo, que eran miembros del cabildo, para que como tales contribuyeran a la obra. Don Joaquín Rubín de Ceballos y don José Rubín de Ceballos respondieron a la petición. El segundo dio cincuenta doblones y el primero argumentó que se los pediría a su padre que era quien administraba su renta AA. CC. 3 de noviembre de 1789 y 7 de enero de 1790, Capitular, AHDJ.

52. Caja 602/12, Archivo General de Palacio, ref. en: José Luis Morales y Marín, Mariano Salvador Maella, El Avapiés, Madrid, 1991, 102. 
y como indica la firma del lienzo «Maella facib ${ }^{t}$ año 1792». El pintor del rey la realizó con celeridad, pese a tener que atender un encargo de la reina María Luisa de Parma que quería un San Julián para los premostratenses de Madrid y que corría bastante prisa porque «(...) todo havía de estar concluido antes de su feliz parto»..$^{53}$ El impacto positivo que causó la Sagrada Familia entre los promotores, alentó el segundo encargo que tendría lugar en 1793, la Asunción de la Virgen para el Sagrario.

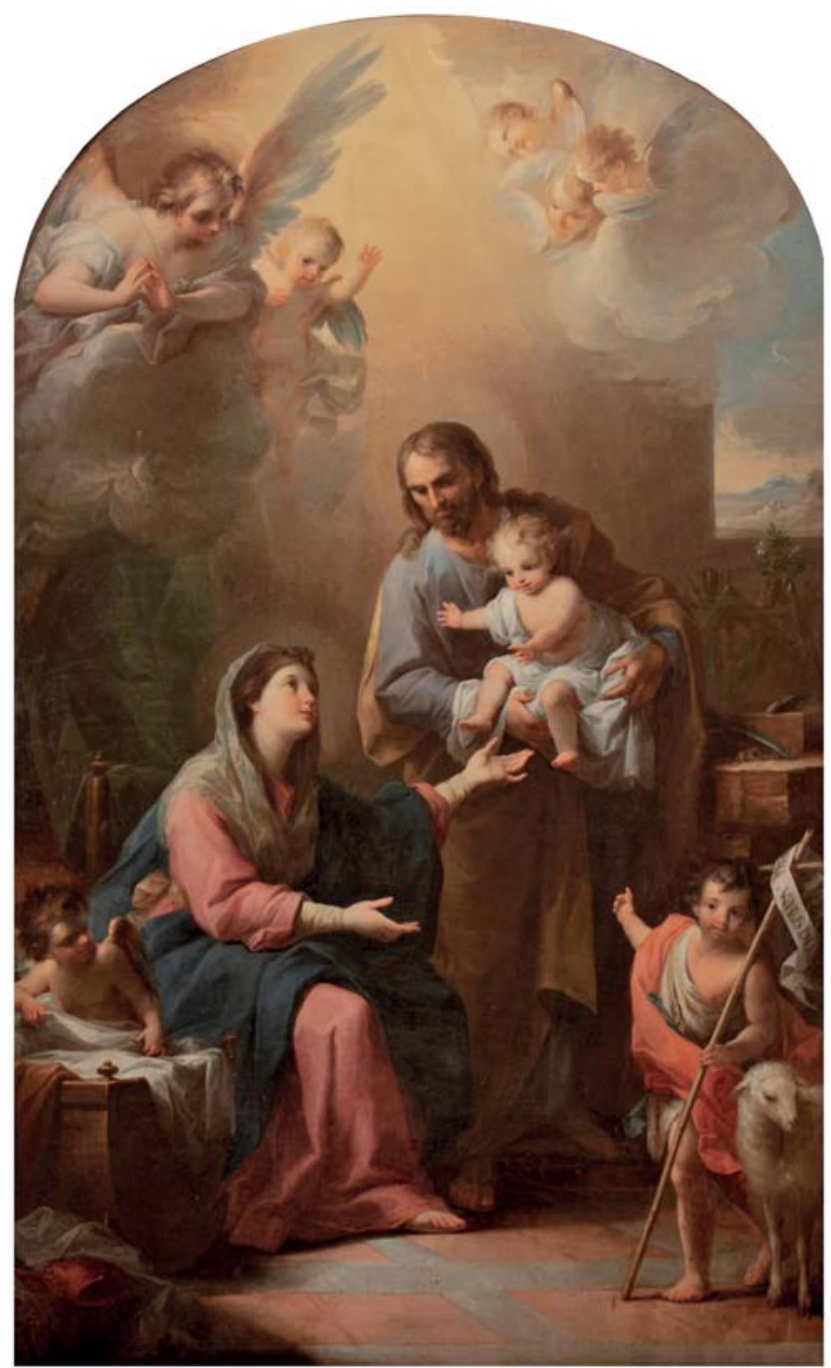

Fig. 6. Mariano Salvador Maella, Sagrada Familia, 1792, 286 x 179 cm, trascoro, catedral de Jaén

53. Mano, J. M. DE LA, Mariano Salvador Maella (1739-1819), Dibujos, Catálogo Razonado, Fundación Botín, Santander, 2011, t. II, 640. 
Con su mediación ante Maella, Rubín de Ceballos pretendía remediar el nefasto resultado del trabajo de Miguel de Verdiguier para el testero del Sagrario. Bien por la inoperancia técnica del anciano maestro o bien por un exceso de desfasado barroquismo, su relieve de tema eucarístico fue duramente criticado y el propio obispo manifestó su profunda decepción por lo costosa que había sido la obra del escultor francés. ${ }^{54}$

En aras de «borrar la intolerable fealdad», don Agustín se había ofrecido «al cabildo para buscar los mejores pintores de la corte». Cumplía así con el requerimiento de Manuel Martín Rodríguez referente a que se sustituyera con una pintura la obra del escultor de Marsella «(...) por haberse ejecutado contra todas las reglas del Arte, sin proporción, y por el más depravado gusto desdiciendo notablemente del orden, primor y magnificencia de la arquitectura que constituye el todo de la obra». Martín Rodríguez exhortaría a «que se encargue el quadro a uno de los profesores más acreditados de la corte (...)». Para acelerar las tareas de decoración de la capilla sacramental de la catedral y para evitar otros despropósitos como los comentados, el maestro mayor incidía en que los dos altares laterales también se ornaran con pinturas que fueran llevadas a cabo por diferentes profesores de la Academia para que, por competencia entre ellos, el resultado fuese de gran calidad. La propuesta no se cumplió exactamente como pedía el arquitecto, pues junto al lienzo del altar mayor encargado a Maella, los otros dos se encomendaron a un solo pintor, su cuñado Zacarías González Velázquez (1763-1834).

El grado de implicación del prelado fue tal, que llegaría a gestionar la concesión de un salón del palacio del duque de Osuna en la calle Leganitos, para la ejecución de las pinturas que 1793 ya estaban comenzadas. El canónigo Juan Antonio de Leruela visitaba el obrador palaciego, ensalzando la maestría de las mismas «cuyo diseño o boceto es prodigioso», ${ }^{55}$ al tiempo que recordaba al deán Martínez de Mazas la necesidad de ajustar el precio total de las telas, recordando que «en inteligencia de que Maella es más pintor y tiene el lienzo principal». El artista valenciano cobraría más que su cuñado, en concreto 28.000 reales, cantidad igual al total de lo percibido por González Velázquez. ${ }^{56}$ El cosario Paredes era el encargado de traer a Jaén los tres lienzos.

54. «Carta del obispo Ceballos al deán», 24 de mayo de 1792, fol. 1, Correspondencia, AHDJ., ref. en: Ulierte VázQuez, L. DE, «La decoración del Sagrario de la catedral de Jaén», Instituto de Estudios Giennenses, 105, 1981, 69 y 80.

55. Higueras Maldonado, J., El Sagrario de la catedral de Jaén (Notas Históricas), Diputación Provincial, Jaén, 1985, 47.

56. De Ulierte, «La decoración del Sagrario...», 72-74. Gregorio Ferro hubiera hecho los tres por 27.000 reales. 


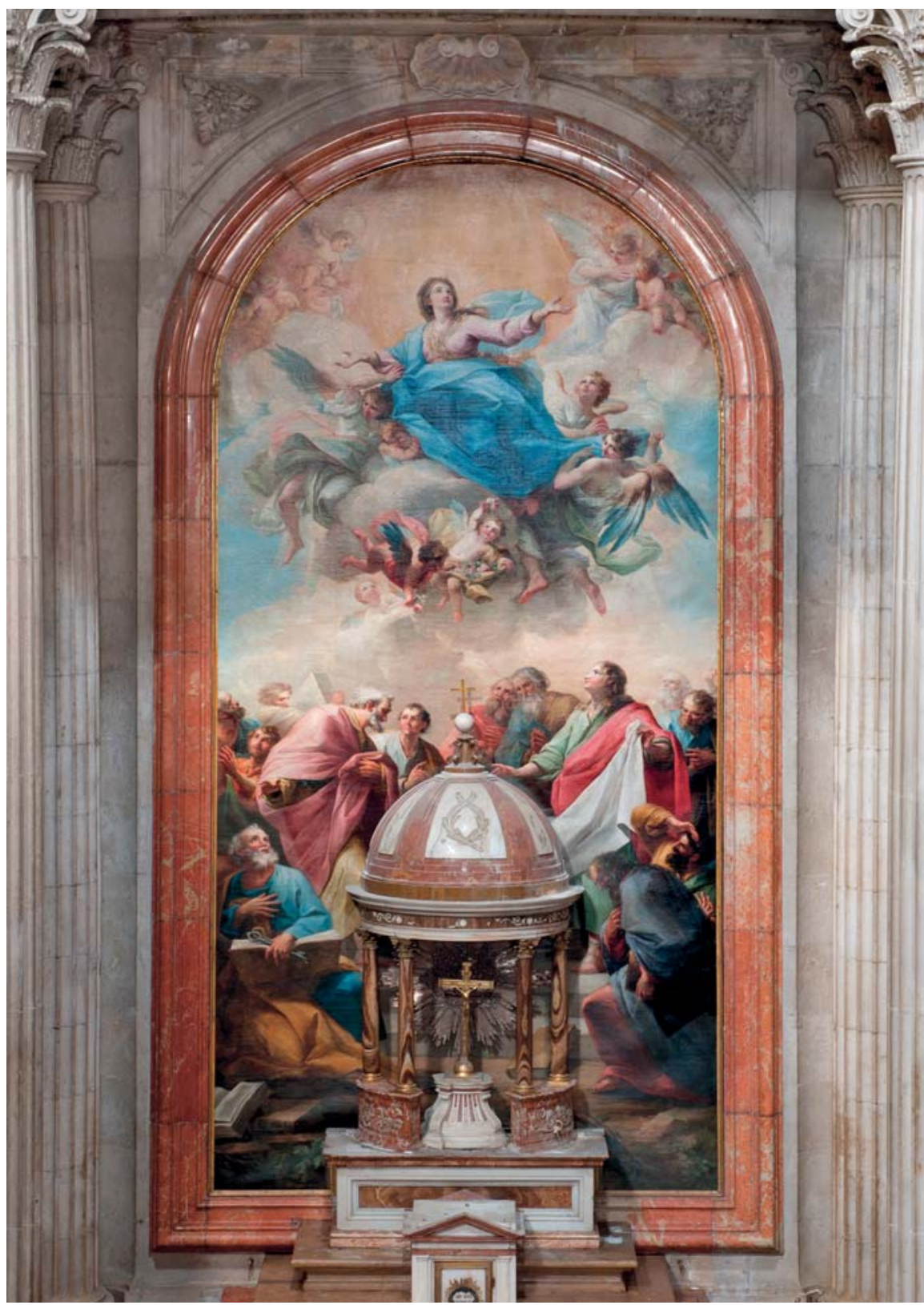

Fig. 7. Mariano Salvador Maella, Asunción de la Virgen, 1793-1794, 660 x 305 cm, Sagrario, catedral de Jaén 